\section{Economics of Pronamide and Pendimethalin Use in Weed Management during Artichoke Stand Establishment}

\author{
Milton J. Haar', Steven A. Fennimore, and Cheryl L. Lambert \\ Department of Vegetable Crops, University of California-Davis, U.S. \\ Department of Agriculture Research Station, 1636 East Alisal Street, Salinas, \\ CA 93905
}

Additional index words. Cynara scolymus, hand-weeding, herbicide value

\begin{abstract}
Field studies were conducted to determine the potential economic impact of the loss of pronamide herbicide to artichoke (Cynara scolymus $\mathbf{L}$.) growers, and to evaluate pendimethalin as an alternative herbicide during establishment of artichoke. Two rates of pronamide and one rate of pendimethalin were applied to perennial and annual artichokes. With the exception of wild oat (Avena fatua L.), pendimethalin controlled weeds as well as or better than pronamide. Financial analysis of treatment effects was based on weed management expenses and value of yield. The financial effect of using pronamide in perennial artichoke ranged from a loss of \$247 to a gain of \$326 per ha, whereas its use in annual artichoke increased revenue $\$ 542$ to $\$ 5499$ per ha. The effects on revenue of using pendimethalin varied with weed species composition and density. For three sites, revenue increased from \$267 to \$5056 per ha, while a loss of \$1034 per ha occurred at a site with a heavy infestation of wild oat. We conclude that pendimethalin has potential as a pronamide replacement, or as a complement to pronamide. Chemical names used: 3,5dichloro ( $N$-1,1-dimethyl-2-propynyl)benzamide (pronamide); $N$-(1-ethylpropyl)-3,4-dimethyl-2,6-dinitrobenzenamine (pendimethalin).
\end{abstract}

Although a minor crop in the United States, artichoke is economically important on a regional basis, with California producing the entire national crop (U.S. Dept. of Agriculture, 1999). In 1998, 41,300 $\mathrm{t}$ was produced on 4330 ha, valued at $\$ 62.9$ million (California Agricultural Statistics Service, 1999). Principal artichoke production areas include: north central coast counties of Monterey, Santa Cruz, and San Mateo; south coast counties of Santa Barbara, Ventura, and Orange; and Imperial and Riverside counties of the low desert in southeast California (U.S. Dept. of Agriculture, 1999).

Weed management is essential for the successful establishment of artichoke stands (Cudney et al., 1999). Broadleaf weeds are common pests in new artichoke plantings, and compete with artichoke for light, water, and nutrients. Pronamide is the only broadleaf herbicide registered for new artichoke plantings (Cudney et al., 1999), but has been classified as a possible human carcinogen, and all tolerances for pronamide are being reviewed by the Environmental Protection Agency (Goldman,

Received for publication 26 Apr. 2000. Accepted for publication 10 Nov. 2000. The cooperation of Lionel Handel, Pezzini Farms, and Sea Mist Farms is gratefully acknowledged. The National Pesticide Impact Assessment Program funded this research. The cost of publishing this paper was defrayed in part by the payment of page charges. Under postal regulations, this paper therefore must be hereby marked advertisement solely to indicate this fact.

${ }^{1}$ To whom reprint requests should be addressed. E-mail address: mjhaar@ucdavis.edu
1997). If pronamide registration in artichoke is cancelled, no herbicides would remain for broadleaf weed control in annual plantings and new perennial plantings.

Artichoke has been traditionally cultivated as a perennial crop. Recently, annual cultivars have provided artichoke producers with a second option (Schrader et al., 1992). Benefits of the annual production system include: 1) a considerable reduction in labor-intensive pruning; 2) harvest during periods of low production for perennial artichoke; and 3) control of certain perennial pests, such as the weed Bermuda buttercup (Oxalis pes-caprae L.) and an important vertebrate pest, the California vole (Microtus californicus Peale) (Lionel Handel, pest control advisor, Kleen Globe Inc., Castroville, Calif., personal communication; Schrader and Mayberry, 1996). Annual artichoke is more dependent on pronamide for weed management than is the perennial cultivar. Perennial artichoke is planted at wide (1m) row spacing, which permits cultivation in two directions. Annual artichoke is planted more densely and cultivated in only one direction. A larger area is left uncultivated in annual artichoke, which requires herbicide application or hand-weeding. Loss of pronamide would affect annual more severely than perennial artichoke production.

Artichoke is grown primarily as a perennial on the central coast, but as an annual crop on the southern coast and in the desert (U.S. Dept. of Agriculture, 1999). Under the perennial production system, it is propagated vegetatively using root portions obtained from mature plants. Propagules are planted from June through September, then maintained for 10 or more years (Schrader and Mayberry, 1996). Annual artichoke is either transplanted or direct-seeded (U.S. Dept. of Agriculture, 1999). On the south coast, artichoke is transplanted from June to August for October to April harvest (Schrader and Mayberry, 1996). Direct-seeding is preferred in the desert areas, and occurs from August to October for January to April harvest. Standard production practices for both annual and perennial artichokes call for new stands to be watered heavily for 30 to $60 \mathrm{~d}$ after transplanting. The wet environment is not only conducive to weed growth, but impedes hand-weeding as well (L. Handel, personal communication). A broadleaf herbicide is vital to weed management during this initial period after planting. In 1997, pronamide was applied to 660 ha of artichoke, primarily to new plantings (L. Handel, personal communication).

Pendimethalin, a dinitroaniline herbicide applied preplant and preemergent in soybeans [Glycine $\max$ (L.) Merrill], and preemergent or postemergent in corn (Zea mays L.), is a potential replacement for pronamide use in new artichoke stands. It controls many grasses and certain broadleaf weeds (Ahrens, 1994). Preliminary studies indicate that transplanted artichokes are tolerant to this herbicide (Cudney et al., 1990), and regulatory evaluation for its registration in artichoke is currently under way (U.S. Dept. of Agriculture, 1999). The primary objective of this research was to estimate the potential economic impact of pronamide loss to artichoke growers by comparing weed control costs and artichoke yields with and without pronamide. The second objective was to evaluate pendimethalin as an alternative herbicide for new artichoke plantings.

\section{Materials and Methods}

Four field experiments were conducted in the artichoke production district of Monterey County. Sites with weed pressure sufficient to detect differences in treatments were selected. Perennial artichoke, cv. Green Globe, was established at two sites near Castroville, Stroebel Ranch, and Pezzini Farm using root portions obtained from mature plants. Row width was $2.7 \mathrm{~m}$, and plants were spaced 0.9 to $1.2 \mathrm{~m}$ apart within the row. Plot size was $5.5 \times$ $27.4 \mathrm{~m}$. Annual artichoke, cv. Imperial Star, stands were established as transplants at another two sites, Armstrong Ranch near Marina, and the U.S. Dept. of Agriculture (USDA) Hartnell Farm at Salinas. Row width was 2.0 $\mathrm{m}$, and plants were spaced $0.6 \mathrm{~m}$ apart within the row. Plot size was $4.0 \times 12.2 \mathrm{~m}$. Soil characteristics and plant and harvest dates for each site are listed in Table 1. Natural weed infestations at each site were as follows: Stroebel Ranch, common chickweed [Stellaria media (L.) Vill.] and wild oat; Pezzini Farm, annual sowthistle (Sonchus oleraceus L.), burning nettle (Urtica urens L.), common chickweed, and wild oat; Armstrong Ranch, corn spurry (Spergula arvensis L.); Hartnell 
Table 1. Artichoke production system, soil type, organic matter, $\mathrm{pH}$, and dates of planting, hand-weeding, and harvesting for four artichoke field sites on the north central coast of California.

\begin{tabular}{|c|c|c|c|c|c|c|c|}
\hline \multirow[b]{2}{*}{$\begin{array}{l}\text { Production } \\
\text { system }\end{array}$} & \multirow[b]{2}{*}{ Site } & \multirow{2}{*}{\multicolumn{2}{|c|}{$\begin{array}{c}\text { Organic } \\
\text { matter } \\
(\%)\end{array}$}} & \multirow[b]{2}{*}{$\mathrm{pH}$} & \multicolumn{3}{|c|}{ Dates of: } \\
\hline & & & & & $\begin{array}{l}\text { Planting } \\
\text { (1998) }\end{array}$ & $\begin{array}{l}\text { Hand-weeding } \\
\text { (1998-99) }\end{array}$ & $\begin{array}{l}\text { Harvesting } \\
(1998-99)\end{array}$ \\
\hline \multirow[t]{2}{*}{ Perennial } & Stroebel Ranch & Diablo clay & 2.1 & $6.1-7.8$ & 22 June & 18 Aug. & 30 Sept. to 26 Apr. \\
\hline & Pezzini Farm & Pachelo clay loam & 2.0 & $6.1-8.4$ & 9 July & 27 Aug. & 1 Oct. to Apr. \\
\hline \multirow[t]{2}{*}{ Annual } & Armstrong Ranch & Oceano loamy sand & 0.1 & $5.6-7.3$ & 16 Nov. & 28 Jan., 10 Mar., and 12 May & 2 June to 23 July \\
\hline & Hartnell Farm & Chualar loam & 2.5 & $6.1-7.8$ & 23 Nov. & 24 Feb. and 21 Apr. & 24 May to 12 July \\
\hline
\end{tabular}

Table 2. Effects of pronamide and pendimethalin on the densities (no. weeds $/ \mathrm{m}^{2}$ ) of eight weed species at annual artichoke field sites.

\begin{tabular}{|c|c|c|c|c|c|c|c|c|c|}
\hline \multirow[b]{2}{*}{ Herbicide } & \multirow[b]{2}{*}{$\begin{array}{c}\text { Rate } \\
\left(\mathrm{kg} \cdot \mathrm{ha}^{-1}\right)\end{array}$} & \multirow{2}{*}{$\begin{array}{c}\text { Armstrong } \\
\text { Corn } \\
\text { spurry }\end{array}$} & \multicolumn{7}{|c|}{ Hartnell } \\
\hline & & & $\begin{array}{c}\text { Annual } \\
\text { bluegrass }\end{array}$ & $\begin{array}{c}\text { Burning } \\
\text { nettle }\end{array}$ & $\begin{array}{l}\text { Common } \\
\text { chickweed }\end{array}$ & $\begin{array}{l}\text { Desert rock- } \\
\text { purslane }\end{array}$ & $\begin{array}{c}\text { Persian } \\
\text { speedwell }\end{array}$ & $\begin{array}{c}\text { Redstem } \\
\text { filaree }\end{array}$ & $\begin{array}{c}\text { Shepherds- } \\
\text { purse }\end{array}$ \\
\hline \multirow[t]{2}{*}{ Pronamide } & 1.1 & $57.8 \mathrm{a}^{\mathrm{z}}$ & $1.0 \mathrm{~b}$ & $7.8 \mathrm{~b}$ & $5.0 \mathrm{~b}$ & $4.2 \mathrm{~b}$ & $4.6 \mathrm{~b}$ & $0.0 \mathrm{~b}$ & $33.2 \mathrm{bc}$ \\
\hline & 1.7 & $47.6 \mathrm{a}$ & $1.6 \mathrm{~b}$ & $5.6 \mathrm{~b}$ & $2.2 \mathrm{~b}$ & $2.0 \mathrm{~b}$ & $2.6 \mathrm{~b}$ & $2.0 \mathrm{~b}$ & $54.6 \mathrm{~b}$ \\
\hline Pendimethalin & 1.1 & $12.8 \mathrm{~b}$ & $8.2 \mathrm{~b}$ & $2.2 \mathrm{~b}$ & $0.0 \mathrm{~b}$ & $0.0 \mathrm{~b}$ & $0.0 \mathrm{~b}$ & $0.0 \mathrm{~b}$ & $0.0 \mathrm{c}$ \\
\hline None & --- & $57.0 \mathrm{a}$ & $150.6 \mathrm{a}$ & $275.0 \mathrm{a}$ & $82.6 \mathrm{a}$ & $78.6 \mathrm{a}$ & $117.6 \mathrm{a}$ & $8.6 \mathrm{a}$ & $145.2 \mathrm{a}$ \\
\hline $\mathrm{LSD}_{0.05}$ & & 33.0 & 26.2 & 45.0 & 27.3 & 47.1 & 60.8 & 4.6 & 49.0 \\
\hline
\end{tabular}

${ }^{2}$ Mean separation within columns by LSD, $P \leq 0.05$.

Farm, annual bluegrass (Poa annua L.), burning nettle, common chickweed, desert rockpurslane [Calandrinia ciliata (R.\&P.) DC. var. menziesii (Hook.) Macbr.], Persian speedwell (Veronica persica Poir.), redstem filaree [Erodium cicutarium (L.) L'Her.], and shepherdspurse [Capsella bursa-pastoris (L.) Medik.].

Pronamide was applied at 2.2 and $1.7 \mathrm{~kg} \cdot \mathrm{ha}^{-}$ ${ }^{1}$ to perennial artichoke and at 1.7 and 1.1 $\mathrm{kg} \cdot \mathrm{ha}^{-1}$ to annual artichoke. Pendimethalin was applied at 2.2 and $1.1 \mathrm{~kg} \cdot \mathrm{ha}^{-1}$ to perennial and annual artichoke, respectively. Both were applied immediately after transplanting with a $\mathrm{CO}_{2}$-pressurized backpack sprayer equipped with $8002 \mathrm{VS}$ nozzles that delivered $187 \mathrm{~L} \cdot \mathrm{ha}^{-}$ ${ }^{1}$ at $276 \mathrm{kPa}$. Spray band width was $1.2 \mathrm{~m}$ for perennial artichoke, and $1.0 \mathrm{~m}$ for annual artichoke, centered on the plant row. Herbicides were incorporated with overhead irrigation. Treatments at each site were arranged in a randomized complete-block design with four replications.

Before plots were hand-weeded, weed infestation was measured by one of two methods: 1 ) weed species were counted in two 0.56 $\times 1 \mathrm{~m}$ randomly selected areas per plot; or 2 ) weed biomass was measured in two $0.1-\mathrm{m}^{2}$ randomly selected areas per plot. In the second method, weeds were cut at the soil line and separated by species, and the fresh mass was measured. Project personnel recorded the time an experienced field worker spent removing weeds from each plot. One individual handweeded all plots for a location and date, but individuals differed among sites and dates. The dates of hand-weeding are shown in Table 1. Artichokes were harvested weekly or biweekly, depending on production and weather, and the buds were weighed and graded by size according to commercial standards. Growers performed all production operations outside the scope of this study according to standard practices for the area.

The two artichoke production systems were analyzed separately. Agriculture Research Manager (Gylling Data Management Inc., Brookings, S.Dak.) was used for data analysis. Data were subjected to analysis of variance
(ANOVA), and tested for location $\times$ treatment interaction. Data were not pooled when location $\times$ treatment interaction was significant. Interaction was significant for site $\times$ handweed time for perennial artichoke and for site $x$ yield interaction for both perennial and annual artichokes. Mean separation was performed using Fisher's protected least significant difference (LSD) at $P \leq 0.05$.

Current prices for weed management expenditures were obtained by contacting local growers and suppliers. Hand-weeding was valued at $\$ 11.30 \mathrm{per} h$, pronamide at $\$ 147.49$ per $\mathrm{kg}$, pendimethalin at $\$ 15.90$ per $\mathrm{kg}$, and herbicide application at $\$ 12.00$ per ha. The cost of weed management for a treatment was determined by adding the hand-weeding, herbicide, and application costs. The value of artichoke yield was calculated based on a standard of $10.4 \mathrm{~kg} / \mathrm{carton}$, and an average value of $\$ 12.00$ per carton (M.A. Bari, Artichoke Research Association, personal communication; Monterey County Agricultural Commissioner, 1998).

The cost of weed management, value of artichoke yield, relative weed management cost, relative yield value, and a net gain or loss for treatments were calculated. Relative weed management costs are comparisons between treated and nontreated plots, and indicate whether the herbicide treatment resulted in a net increase or decrease in expense. Relative yield values represent an increase or decrease in yield associated with a treatment. Addition of the relative weed management cost and yield value gave a net treatment gain or loss.

Table 3. Effect of pronamide and pendimethalin on the biomass (Pezzini Farm) or density (Stroebel Ranch) of weeds infesting perennial artichoke.

\begin{tabular}{|c|c|c|c|c|c|c|c|}
\hline \multirow[b]{2}{*}{ Herbicide } & \multirow[b]{2}{*}{$\begin{array}{c}\text { Rate } \\
\left(\mathrm{kg} \cdot \mathrm{ha}^{-1}\right)\end{array}$} & \multicolumn{4}{|c|}{ Weed biomass $\left(\mathrm{g} \cdot \mathrm{m}^{-2}\right)$ at Pezzini Farm } & \multicolumn{2}{|c|}{$\begin{array}{c}\text { Weed density }\left(\text { no. } / \mathrm{m}^{2}\right) \\
\text { at Stroebel Ranch }\end{array}$} \\
\hline & & $\begin{array}{c}\text { Annual } \\
\text { sowthistle }\end{array}$ & $\begin{array}{c}\text { Burning } \\
\text { nettle }\end{array}$ & $\begin{array}{c}\text { Common } \\
\text { chickweed }\end{array}$ & $\begin{array}{c}\text { Wild } \\
\text { oat }\end{array}$ & $\begin{array}{l}\text { Common } \\
\text { chickweed }\end{array}$ & $\begin{array}{c}\text { Wild } \\
\text { oat }\end{array}$ \\
\hline \multirow[t]{2}{*}{ Pronamide } & 1.7 & $145.3 \mathrm{ab}^{\mathrm{z}}$ & $1.1 \mathrm{~b}$ & $29.9 \mathrm{~b}$ & $0.5 \mathrm{~b}$ & $0.6 \mathrm{~b}$ & $20.0 \mathrm{~b}$ \\
\hline & 2.2 & $128.1 \mathrm{ab}$ & $1.1 \mathrm{~b}$ & $5.4 \mathrm{~b}$ & $0.2 \mathrm{~b}$ & $1.2 \mathrm{~b}$ & $27.2 \mathrm{~b}$ \\
\hline Pendimethalin & 2.2 & $1.1 \mathrm{~b}$ & $0.0 \mathrm{~b}$ & $1.1 \mathrm{~b}$ & $9.6 \mathrm{ab}$ & $0.0 \mathrm{~b}$ & $91.2 \mathrm{a}$ \\
\hline None & --- & $200.2 \mathrm{a}$ & $54.9 \mathrm{a}$ & $218.5 \mathrm{a}$ & $14.7 \mathrm{a}$ & $3.0 \mathrm{a}$ & $92.2 \mathrm{a}$ \\
\hline $\mathrm{LSD}_{0.05}$ & & 169.9 & 45.0 & 60.9 & 8.2 & 1.7 & 48.6 \\
\hline
\end{tabular}

${ }^{2}$ Mean separation within columns by LSD, $P \leq 0.05$.
Weed control. Pronamide did not reduce the density of corn spurry plants significantly at Armstrong Ranch, but pendimethalin did (Table 2). Differences among the two pronamide treatments were nonsignificant at Hartnell Farm. Both rates of pronamide and pendimethalin reduced the densities of annual bluegrass, burning nettle, common chickweed, desert rockpurslane, Persian speedwell, redstem filaree, and shepherdspurse. At Pezzini Farm, pendimethalin significantly reduced annual sowthistle biomass (Table 3), but pronamide did not. Both herbicides were effective on burning nettle and common chickweed. Pronamide was effective on light wild oat populations at Pezzini Farm, but control was incomplete at the Stroebel site. either site.

Hand-weeding time. Both pronamide treatments reduced the time required to hand-weed perennial artichoke at Stroebel Ranch, but pendimethalin did not (Table 4). At the Pezzini Farm, $2.2 \mathrm{~kg} \cdot \mathrm{ha}^{-1}$ pronamide reduced weeding time, whereas the lower rate of pronamide did not. The pendimethalin treatment was most effective at this site. Both pronamide treatments reduced the time required to hand-weed annual artichoke. In annual artichoke, pronamide was partially effective, but application of pendimethalin was most effective.

Yield. Yield of perennial artichoke was not affected by pronamide treatment at either site (Table 4). The effect of pendimethalin varied Pendimethalin was ineffective on wild oat at 
with site; it reduced yield at Stroebel Ranch, but increased it at Pezzini Farm. At Armstrong Ranch, annual artichoke yield was not affected by the lower rate of pronamide or pendimethalin, but the higher rate of pronamide increased yield. At Hartnell Farm, all treatments increased yields.

Yield quality. Pronamide did not affect bud quality of perennial artichoke (Table 5), but pendimethalin reduced the number of size 12 buds. The total number of perennial buds did not differ among treatments. In annual artichoke, the higher rate of pronamide increased the number of size 36 buds and the lower rate increased the number of size 24 buds; both treatments increased the total number of annual buds.

Economic analysis. Pronamide treatments increased relative weed management costs by $\$ 61$ to $\$ 118$ per ha for perennial artichokes, but reduced them by $\$ 427$ to $\$ 765$ per ha for annual artichokes (Table 6). Pendimethalin reduced weed management expenses at Pezzini Farm, Armstrong Ranch, and Hartnell Farm, but not at Stroebel Ranch, where wild oat was the dominant weed. The difference in relative weed management costs between annual and perennial artichokes is primarily attributable to the expense of hand-weeding. Annual artichokes were hand-weeded two or three times, depending on the site, while perennial artichokes were hand-weeded once. A larger area of annual artichoke is hand-weeded because it is cultivated in one direction, whereas perennial artichoke is cultivated in two directions, greatly reducing the area that requires handweeding.

The lower rate of pronamide increased the value of the perennial artichoke yield by $\$ 176$ and $\$ 387$ per ha, while the higher rate reduced relative yield. In annual artichoke, pronamide at both rates added $\$ 115$ to $\$ 4848$ to the yield value per ha. The effects of pendimethalin varied among sites. Greater economic returns were observed at Pezzini and Hartnell Farms (\$2205 and \$3713 per ha, respectively), but value was reduced $\$ 1000$ per ha at Stroebel and $\$ 670$ per ha at Armstrong Ranch.

For perennial artichokes, the lower rate of pronamide increased income $\$ 326$ and $\$ 58$ per ha at Stroebel Ranch and Pezzini Farm, respectively, but greater yield value did not compensate for the added expense of the higher rate of pronamide. For annual artichoke, pronamide increased overall financial benefits $\$ 542$ to $\$ 5499$ per ha. The overall cost or benefit of pendimethalin varied among sites for both artichoke types. At Pezzini Farm, Armstrong Ranch, and Hartnell Farm, overall benefits of $\$ 2273, \$ 267$, and $\$ 5056$ per ha were obtained, respectively. At Stroebel Ranch, however, costs exceeded return by $\$ 1034$ per ha. The financial loss at Stroebel Ranch can be attributed to pendimethalin's inactivity on wild oat, the effects of competition from wild oat on yield and the expense of controlling this weed by hand.

Results of this study indicate that the loss of pronamide would have a significant economic impact on annual artichoke production system. Without pronamide, weed management
Table 4. Effects of pronamide and pendimethalin on the time required to hand-weed and on yield of perennial and annual artichokes at four field sites: Stroebel Ranch, Pezzini Farm, Armstrong Ranch, and Hartnell Farm.

\begin{tabular}{|c|c|c|c|c|c|c|}
\hline \multirow[b]{2}{*}{ Herbicide } & \multicolumn{3}{|c|}{ Perennial artichoke } & \multicolumn{3}{|c|}{ Annual artichoke } \\
\hline & $\begin{array}{c}\text { Rate } \\
\left(\mathrm{kg} \cdot \mathrm{ha}^{-1}\right)\end{array}$ & Stroebel & Pezzini & $\begin{array}{c}\text { Rate } \\
\left(\mathrm{kg} \cdot \mathrm{ha}^{-1}\right)\end{array}$ & Armstrong & Hartnell \\
\hline \multicolumn{7}{|c|}{ Hand-weeding time $\left(h \cdot h a^{-1}\right)$} \\
\hline \multirow[t]{2}{*}{ Pronamide } & 1.7 & $5.5 \mathrm{~b}^{\mathrm{z}}$ & $17.2 \mathrm{ab}$ & 1.1 & \multicolumn{2}{|c|}{$96.9 \mathrm{~b}^{\mathrm{y}}$} \\
\hline & 2.2 & $6.4 \mathrm{~b}$ & $14.3 \mathrm{~b}$ & 1.7 & \multicolumn{2}{|c|}{$95.5 \mathrm{~b}$} \\
\hline Pendimethalin & 2.2 & $11.6 \mathrm{a}$ & $9.2 \mathrm{c}$ & 1.1 & \multicolumn{2}{|c|}{$55.2 \mathrm{c}$} \\
\hline None & --- & $12.6 \mathrm{a}$ & $19.2 \mathrm{a}$ & --- & \multicolumn{2}{|c|}{$159.5 \mathrm{a}$} \\
\hline $\mathrm{LSD}_{0.05}$ & & 2.7 & 3.5 & & \multicolumn{2}{|c|}{14.5} \\
\hline \multicolumn{7}{|c|}{ Yield $\left(\mathrm{kg} \cdot \mathrm{ha} \mathrm{a}^{-1}\right)$} \\
\hline \multirow[t]{2}{*}{ Pronamide } & 1.7 & $6525 \mathrm{a}$ & $5625 \mathrm{ab}$ & 1.1 & $9,359 \mathrm{~b}$ & $11,050 \mathrm{a}$ \\
\hline & 2.2 & $6066 \mathrm{a}$ & $5467 \mathrm{~b}$ & 1.7 & $10,595 \mathrm{a}$ & $11,907 \mathrm{a}$ \\
\hline Pendimethalin & 2.2 & $5323 \mathrm{~b}$ & $7386 \mathrm{a}$ & 1.1 & $8,678 \mathrm{~b}$ & $10,923 \mathrm{a}$ \\
\hline Untreated & --- & $6190 \mathrm{a}$ & $5475 \mathrm{~b}$ & --- & $9,259 \mathrm{~b}$ & $7,705 \mathrm{~b}$ \\
\hline $\mathrm{LSD}_{0.05}$ & & 743 & 1852 & & 1,055 & 2,596 \\
\hline
\end{tabular}

${ }^{\mathrm{z}}$ Mean separation within columns by LSD, $P \leq 0.05$.

${ }^{y}$ Hand-weeding times were pooled for Armstrong and Hartnell sites.

Table 5. Effect of pronamide and pendimethalin on yield (buds/ha) of perennial and annual artichoke within size categories. Data are means for two field sites.

\begin{tabular}{|c|c|c|c|c|c|c|c|}
\hline \multirow{2}{*}{$\begin{array}{l}\text { Production } \\
\text { system }\end{array}$} & \multirow[b]{2}{*}{ Herbicide } & \multirow{2}{*}{$\begin{array}{c}\text { Rate } \\
\left(\mathrm{kg} \cdot \mathrm{ha}^{-1}\right)\end{array}$} & \multicolumn{5}{|c|}{ Size category $^{\mathrm{z}}$ (buds/ha) } \\
\hline & & & 36 & 24 & 18 & 12 & Total \\
\hline \multirow[t]{5}{*}{ Perennial $^{\mathrm{y}}$} & Pronamide & 1.7 & $2777 a^{x}$ & $6192 \mathrm{a}$ & $571 \mathrm{a}$ & $239 a b$ & $9,780 \mathrm{a}$ \\
\hline & & 2.2 & 2923 a & $5940 \mathrm{a}$ & $452 \mathrm{a}$ & 399 a & $9,714 \mathrm{a}$ \\
\hline & Pendimethalin & 2.2 & $4066 \mathrm{a}$ & $6578 \mathrm{a}$ & $651 \mathrm{a}$ & $173 \mathrm{~b}$ & $11,468 \mathrm{a}$ \\
\hline & None & & $2698 \mathrm{a}$ & $6086 \mathrm{a}$ & $611 \mathrm{a}$ & $266 \mathrm{ab}$ & $9,674 \mathrm{a}$ \\
\hline & $\mathrm{LSD}_{0.05}$ & & --- & --- & --- & 195 & --- \\
\hline \multirow[t]{5}{*}{ Annualw $^{w}$} & Pronamide & 1.1 & $2785 \mathrm{ab}$ & $14,289 \mathrm{a}$ & $4682 \mathrm{a}$ & 3956 a & $25,671 \mathrm{a}$ \\
\hline & & 1.7 & $3633 \mathrm{a}$ & $13,320 \mathrm{ab}$ & 5893 a & 4965 a & $27,810 \mathrm{a}$ \\
\hline & Pendimethalin & 1.1 & $2745 \mathrm{ab}$ & $12,674 \mathrm{ab}$ & $5812 \mathrm{a}$ & $3875 \mathrm{a}$ & $25,065 \mathrm{ab}$ \\
\hline & None & & $2341 \mathrm{~b}$ & $11,302 \mathrm{~b}$ & $4561 \mathrm{a}$ & $3754 \mathrm{a}$ & $21,917 \mathrm{~b}$ \\
\hline & $\mathrm{LSD}_{0.05}$ & & 1294 & 2,462 & --- & --- & 3,314 \\
\hline
\end{tabular}

${ }^{\mathrm{z}}$ Size categories represent the number of buds per standard 10.4-kg carton

y Pooled data from Pezzini and Stroebel sites.

${ }^{x}$ Mean separation within columns and production systems by LSD, $P \leq 0.05$.

wPooled data from Armstrong and Hartnell sites.

Table 6. Gain or loss (\$/ha) from using herbicides on perennial and annual artichokes.

\begin{tabular}{|c|c|c|c|c|c|c|c|}
\hline \multirow[b]{2}{*}{ Site } & \multirow[b]{2}{*}{ Herbicide } & \multirow{2}{*}{$\begin{array}{c}\text { Rate } \\
\left(\mathrm{kg} \cdot \mathrm{ha}^{-1}\right)\end{array}$} & \multicolumn{2}{|c|}{$\begin{array}{c}\text { Cost of } \\
\text { weed management }{ }^{2} \\
\end{array}$} & \multicolumn{2}{|c|}{ Value of yield ${ }^{y}$} & \multirow{2}{*}{$\begin{array}{r}\text { Net gain } \\
\text { or loss }\end{array}$} \\
\hline & & & Total & Relative $^{\mathrm{x}}$ & Total & Relative & \\
\hline \multicolumn{8}{|c|}{ Perennial production system } \\
\hline Stroebel & Pronamide & 1.7 & 203 & -61 & 7529 & 387 & 326 \\
\hline \multirow[t]{3}{*}{ Ranch } & & 2.2 & 246 & -104 & 6999 & -143 & -247 \\
\hline & Pendimethalin & 2.2 & 176 & -34 & 6142 & -1000 & -1034 \\
\hline & None & & 142 & 0 & 7142 & 0 & 0 \\
\hline Pezzini & Pronamide & 1.7 & 335 & -118 & 6493 & 176 & 58 \\
\hline \multirow[t]{3}{*}{ Farm } & & 2.2 & 335 & -118 & 6308 & -9 & -128 \\
\hline & Pendimethalin & 2.2 & 149 & 68 & 8522 & 2205 & 2273 \\
\hline & None & & 217 & 0 & 6317 & 0 & 0 \\
\hline \multicolumn{8}{|c|}{ Annual production system } \\
\hline Armstrong & Pronamide & 1.1 & 1051 & 427 & 10,799 & 115 & 542 \\
\hline \multirow[t]{3}{*}{ Ranch } & & 1.7 & 993 & 485 & 12,225 & 1542 & 2027 \\
\hline & Pendimethalin & 1.1 & 541 & 937 & 10,013 & -670 & 267 \\
\hline & None & & 1478 & 0 & 10,683 & 0 & 0 \\
\hline Hartnell & Pronamide & 1.1 & 1362 & 765 & 12,750 & 3860 & 4625 \\
\hline \multirow[t]{3}{*}{ Farm } & & 1.7 & 1476 & 651 & 13,739 & 4848 & 5499 \\
\hline & Pendimethalin & 1.1 & 783 & 1343 & 12,603 & 3713 & 5056 \\
\hline & None & & 2127 & 0 & 8,890 & 0 & 0 \\
\hline
\end{tabular}

${ }^{2}$ Includes the costs of hand-weeding, herbicide, and herbicide application.

y Calculated using a standard of $10.4 \mathrm{~kg}$ per carton and an average value of $\$ 12.00$ per carton.

${ }^{x}$ Relative to controls. 
in annual artichoke stands is more expensive and yields may be lower because of weed competition. A similar trend, however, was not found for perennial artichokes. At current prices, hand-weeding in perennial artichokes is as cost-effective as applying pronamide. Pendimethalin has potential as a replacement for pronamide, or as a complement to pronamide use, depending on weed composition. At sites where broadleaf weeds dominated, pendimethalin controlled weeds as well as, or better than, pronamide.

\section{Literature Cited}

Ahrens, W.H. (ed.). 1994. Herbicide handbook. 7th ed. Weed Sci. Soc. Amer., Champaign, Ill.

California Agricultural Statistics Service. 1999. Calif. Vegetable Rev. 20(1). Available online at http://www.nass.usda.gov/ca/

Cudney, D.W., W.L. Schrader, H.S. Agamalian, and K.S. Mayberry. 1990. Artichoke herbicide evaluation, p. 149-150. In: Res. Progress Rpt. Western Soc. Weed Sci.

Cudney, D.W., R.F. Smith, W.L. Schrader, and B.F. Mullen. 1999. Univ. California pest management guidelines. Div. Agr. Natural Resources Publ. 3339. Available online at http://www. ipm.ucdavis.edu/PMG/selectnewpest. artichoke.html

Goldman, L.R. 1997. Raw and processed food schedule for pesticide tolerance reassessment notice. Federal Register 67:42019-42030.
Monterey County Agricultural Commissioner. 1998. Approximate weights used for fresh market conversion. Monterey County Agr. Commissioner Crop Rpt., Salinas, Calif.

Schrader, W.L., K.S. Mayberry, and D.W. Cudney. 1992. Paving the way to a better artichoke. California Agr. 46:(4)28-29.

Schrader W.L. and K.S. Mayberry. 1996. Artichoke production in California. Univ. California Div. Agr. Natural Resources Publ. 7221. Available online at http://vric.ucdavis.edu/selectnewcrop. artichoke.htm

U.S. Dept. of Agriculture. 1999. Crop profile for artichokes in California. Office of Pest Mgt. Policy and Pesticide Impact Assessment Prog. Available online at http://pestdata.ncsu.edu/ cropprofiles/docs/caartichokes.html 